\title{
CCL113, a novel sulfonamide, induces selective mitotic arrest and apoptosis in HeLa and HepG2 cells
}

\author{
RUIRONG YI $^{1}$, YOSHIFUMI OHNO ${ }^{1}$, ZHENG TIAN $^{1}$, SHUHAN GUO $^{1}$, WEIWEI CHEN ${ }^{1}$, XUE MA $^{1}$, \\ NAN NWE WIN $^{1}$, QISEN LI ${ }^{1}$, MAJID VAHED ${ }^{1}$, KENGO SAITO $^{1}$, SHINGO NAKAMOTO ${ }^{1}$, \\ AKIKO SUGANAMI ${ }^{1-3}$, NAOHISA ISEGAWA ${ }^{1}$, KEISUKE YOSHIDA ${ }^{4}$, SHINJI HARADA ${ }^{3,4}$, \\ YUTAKA TAMURA $^{2,3}$, ATSUSHI NISHIDA ${ }^{3,4}$ and HIROSHI SHIRASAWA ${ }^{1}$ \\ Departments of ${ }^{1}$ Molecular Virology and ${ }^{2}$ Bioinformatics, Graduate School of Medicine, Chiba University; \\ ${ }^{3}$ Molecular Chirality Research Center; and ${ }^{4}$ Graduate School of Pharmaceutical Sciences, \\ Chiba University, Chuo-ku, Chiba 260-8670, Japan
}

Received October 11, 2019; Accepted September 14, 2020

DOI: 10.3892/or.2020.7805

\begin{abstract}
Targeting cell-cycle regulation to hinder cancer cell proliferation is a promising anticancer strategy. The present study investigated the effects of a novel sulfonamide, CCL113, on cell cycle progression in cancer cell lines (HeLa and HepG2), a noncancerous cell line (Vero) and a normal human fibroblast cell line (TIG-1-20). The present results showed that treatment with CCL113 significantly decreased the viability of the cancer cells. FACS analyses showed that CCL113 treatment increased the proportion of cancerous and noncancerous cells in the $G_{2} / M$ phase. Analyses of cell cycle regulatory proteins showed that CCL113 treatment inhibited the activity of CDK1 in HeLa cells, possibly due to the decrease in the level of $\mathrm{Cdc} 25 \mathrm{~B} / \mathrm{C}$ proteins and arrest in the $\mathrm{M}$ phase. Using time-lapse imaging-assisted analyses of HeLa and Vero cells expressing fluorescent ubiquitination-based cell cycle indicator (FUCCI), it was observed that CCL113 treatment led to a prolonged $\mathrm{G}_{2}$ phase at the $\mathrm{G}_{2} / \mathrm{M}$ checkpoint and arrest in the $\mathrm{M}$ phase in both cell lines. This possibly activated the DNA damage response in noncancerous cells, while inducing mitotic arrest leading to apoptosis in the cancer cells. The results of molecular docking studies suggested that CCL113 might have the potential to bind to the taxol-binding site on $\beta$-tubulin. In conclusion, CCL113 holds potential as a reliable anticancer drug due to its ability to induce mitotic arrest followed by apoptosis of cancer cells and to activate the DNA damage response in noncancerous cells, thereby facilitating exit from the cell cycle.
\end{abstract}

Correspondence to: Professor Hiroshi Shirasawa, Department of Molecular Virology, Graduate School of Medicine, Chiba University, 1-8-1 Inohana, Chuo-ku, Chiba 260-8670, Japan

E-mail: sirasawa@faculty.chiba-u.jp

Key words: sulfonamide, $\mathrm{M}$ phase arrest, apoptosis, $\mathrm{Cdc} 25, \mathrm{G}_{2} / \mathrm{M}$ checkpoint

\section{Introduction}

Cell-cycle regulatory proteins such as CDKs, cyclins, and CDK inhibitors regulate the progression through $\mathrm{G}_{1}, \mathrm{~S}, \mathrm{G}_{2}$, and $\mathrm{M}$ phases of the cell cycle (1). However, cancer cells exhibit dysregulated expression of these proteins, and hence, they continue to divide by undergoing uncontrolled cell cycles (2). Targeting cell-cycle regulators to hinder cancer cell proliferation is a promising anti-cancer strategy. Given the crucial role of CDK complexes in cell cycle regulation, several drugs targeting CDKs have been developed and tested in clinical trials (3-7). In addition, activators of CDKs, such as serine/threonine-protein kinase PLK1 (Plk1), Aurora kinase and $\mathrm{Cdc} 25$ phosphatases $(\mathrm{Cdc} 25 \mathrm{~A} / \mathrm{B} / \mathrm{C})$ are attractive targets for the development of anticancer drugs, and a number of specific inhibitors targeting these proteins have been studied and tested in clinical trials (8-12).

Mitotic entry and progression are regulated by the activity of the CDK1-cyclin B complex and controlled by multiple feedback loops (13-15). The regulatory molecules myelin transcription factor 1 (Myt1) and Weel-like protein kinase (Weel) inhibit the activity of the CDK1-cyclin B complex during the $\mathrm{G}_{2}$ phase by phosphorylating CDK1 at Tyr15 and Thr14, while the $\mathrm{Cdc} 25$ phosphatase family activates the complex by dephosphorylation of these sites $(16,17)$. In addition, several feedback loops, such as Plk1-dependent positive feedback and Bora-Aurora-Plk1 feedback, indirectly regulate the activity of the CDK1-cyclin B complex (15).

DNA damage leads to the activation of checkpoint kinases such as ATM kinases (targeting Ser residues) and ATR kinases (targeting Ser/Thr), which further activate p53 and downstream effector kinases, such as serine/threonine-protein kinase Chk1 (Chk1) and serine/threonine-protein kinase Chk2 (Chk2) (18). DNA damage during the $\mathrm{G}_{2}$ phase evokes the DNA damage response, thereby inhibiting Plk1 and Cdc25, leading to cell cycle arrest at the $\mathrm{G}_{2} / \mathrm{M}$ checkpoint, irrespective of the $\mathrm{p} 53$ status (18). Entry into the $M$ phase is prevented through inhibitory phosphorylation of CDK1 by Cdc 25 or by sequestration of cyclin B outside the nucleus $(18,19)$. During $\mathrm{G}_{2}$ arrest in 
response to DNA damage, p53, p21, and $\mathrm{APC} / \mathrm{C}^{\mathrm{cdh} 1}$ (the anaphase-promoting complex/cyclosome and its coactivator Cdh1) are required to permanently exit the cell cycle (19-21). In cancer cell lines with functionally compromised p21, the cells are unable to exit the cell cycle $(21,22)$.

Mitotic arrest can also induce DNA damage response (23). Microtubule-targeting agents, which are commonly used as anticancer drugs, disrupt microtubule dynamics and arrest cells in the $\mathrm{G}_{2} / \mathrm{M}$ phases (24-26). This may activate the DNA damage response, eventually activating p53 and p21, and inducing apoptosis in cancer cells $(27,28)$.

The present study screened a chemical compound library and identified CCL113, a novel sulfonamide, as a candidate anticancer drug. The present study elucidated the effects of CCL113 on cell cycle progression using cancerous and noncancerous cell lines and found that CCL113 selectively induced mitosis and apoptosis in cancer cells.

\section{Materials and methods}

Cell lines. Cervical cancer-derived HeLa cells were obtained from the American Type Culture Collection. Monkey-kidney-derived Vero, liver-cancer-derived HepG2, and normal human fibroblasts, TIG-1-20 cells were obtained from the National Institutes of Biomedical Innovation, Health and Nutrition, Japan. Cells were grown in DMEM (Sigma-Aldrich; Merck KGaA) supplemented with 10\% FBS (Thermo Fisher Scientific, Inc.) and antibiotics (penicillin, $100 \mathrm{U} / \mathrm{ml}$; streptomycin, $100 \mu \mathrm{g} / \mathrm{ml}$ and amphotericin $\mathrm{B}, 0.25 \mu \mathrm{g} / \mathrm{ml}$ ) at $37^{\circ} \mathrm{C}$ and $5 \% \mathrm{CO}_{2}$. The HeLa-Fucci and Vero-Fucci cell lines were established as previously described (29).

Reverse transcription-quantitative PCR (RT-qPCR). Total RNA was isolated from HeLa cells using TRIzol ${ }^{\circledR}$ reagent (Invitrogen; Thermo Fisher Scientific, Inc.) according to the manufacturer's protocol. Double-stranded cDNA was synthesized from $20 \mathrm{mg}$ total RNA using Ready-to-Go You-Prime First-Strand Beads (GE Healthcare) and Oligo(dT) primers (Sigma-Aldrich; Merck KGaA) according to the manufacturer's instructions. qPCR was performed using a LightCycler FastStart DNA Master SYBR Green 1 Kit (Roche Diagnostics $\mathrm{GmbH}$ ) according to the manufacturer's protocol. The transcript levels of Cdc25 (forward, 5'-AGCGAAGATGATGAC GGATT-3' and reverse, 5'-GCAGAGATGAAGAGCCAA AGA-3') were estimated from the respective standard curves and normalized to the expression of GAPDH (forward, 5'-CAT CTCTGCCCCCTCTGCTGA-3' and reverse, 5'-GGATGA CCTTGCCCACAGCCT-3') determined in corresponding samples. The following thermocycling conditions were used for the qPCR: Initial denaturation for $3 \mathrm{~min}$ at $95^{\circ} \mathrm{C}$, followed by 40 cycles of denaturation at $94^{\circ} \mathrm{C}$ for $30 \mathrm{sec}$, annealing at $60^{\circ} \mathrm{C}$ for $15 \mathrm{sec}$ and elongation at $72^{\circ} \mathrm{C}$ for $30 \mathrm{sec}$. The experiments were performed in triplicate.

Chemical compounds. (R)-5-(methoxymethyl)-1(phenylsulfonyl)-1,5-dihydro-2H-pyrrol-2-one (CCL113) was provided by the Chiba Chemical Library (Fig. 1). It was synthesized from d-pyroglutamic acid, and the schematic diagram is shown in Supplementary Fig. S1 (30). CCL113 was dissolved in DMSO (FUJIFILM Wako Pure Chemical Corporation) to obtain a 20-mM stock solution. Nocodazole (Sigma-Aldrich; Merck KGaA) was dissolved in DMSO at $100 \mu \mathrm{g} / \mathrm{ml}$. DMSO was used as the vehicle control.

Cell viability. Cells $\left(2 \times 10^{3}\right.$ cells/well) were seeded in 96-well plates. After $24 \mathrm{~h}$ of culture, cells were treated with increasing concentrations $(1,5,10,20,30$, and $40 \mu \mathrm{M})$ of CCL113 and incubated for $24 \mathrm{~h}$. DMSO $(<0.05 \%)$ was used as the vehicle control, based on a previous report (31). Cell viability was determined using the CellTiter-Glo Luminescent Cell Viability Assay (Promega Corporation). Luminescent signals were measured using a Wallac 1420 multilabel counter (PerkinElmer, Inc.) and presented as the proportional viability (\%) by comparing the viability of CCL113-treated cells with the DMSO-treated cells.

Staining and imaging of cultured cells. For phase contrast microscopy, HeLa, Vero, HepG2, and TIG-1-20 cells were treated with DMSO or $10 \mu \mathrm{M}$ CCL113 for 8 and $24 \mathrm{~h}$. Following treatment with $10 \mu \mathrm{M}$ CCL113 for 8 and $24 \mathrm{~h}$, the cells were stained with Hoechst 33342 (Thermo Fisher Scientific, Inc.) and incubated for $5 \mathrm{~min}$ at $37^{\circ} \mathrm{C}$. Subsequently, the cells were visualized at x100 magnification with a UV-2A filter (excitation wavelength $365 \mathrm{~nm}$; emission wavelength $400 \mathrm{~nm}$ ) on a Nikon Eclipse TE2000-U microscope (Nikon Corporation). Mitotic cells stained with Hoechst 33342 were identified morphologically, and the mean number of mitotic cells in 10 random visual fields was used as the mitotic index. For imaging of HeLa-Fucci and Vero-Fucci cells, $3 \times 10^{4}$ cells were grown in 35-mm dishes in DMEM with 10\% FBS. Following overnight incubation at $37^{\circ} \mathrm{C}$ and $5 \% \mathrm{CO}_{2}$, cells were synchronized at the $G_{1} / S$ phase by the double thymidine block $(2 \mathrm{mM})$ method (32); thymidine was added into the culture medium at a final concentration of $2 \mathrm{mM}$ and incubated for $14 \mathrm{~h}$. The medium was removed, and cells were washed with PBS. Fresh cell culture medium was added, the cells were incubated for $9 \mathrm{~h}$ and $2 \mathrm{mM}$ thymidine blocking solution was added for the second time and incubated for an additional $14 \mathrm{~h}$. The medium was removed and washed with PBS, and fresh culture medium was added. Next, the cells were exposed to $10 \mu \mathrm{M}$ CCL113 and visualized by time-lapse imaging using a computer-assisted fluorescence microscope (FV10i; Olympus Corporation). Images were recorded every $30 \mathrm{~min}$. Two filter cubes were chosen for fluorescence imaging: mKusabira-orange (excitation wavelength $548 \mathrm{~nm}$; emission wavelength $559 \mathrm{~nm}$ ) to observe Fucci orange, and Azami-Green (excitation wavelength $493 \mathrm{~nm}$; emission wavelength $505 \mathrm{~nm}$ ) to observe Fucci green. Fluoview version 3.1 software (Olympus Corporation) was used for acquiring and analyzing images.

Cell cycle analysis. HeLa, Vero, HepG2, and TIG-1-20 cells were treated with CycleTEST ${ }^{\text {тм }}$ PLUS DNA Reagent kit (Becton, Dickinson and Company) according to the manufacturer's protocol and analyzed using a BD Accuri ${ }^{\mathrm{TM}}$ C6 Flow Cytometer (Becton-Dickinson and Company) equipped with the FACScan fluorescence 2 (FL2) detector. The data were analyzed using FlowJo 7.6.5 software (FlowJo, LLC).

Western blotting. Cells were collected and washed twice with PBS, and then resuspended in M-PER ${ }^{\circledR}$ Mammalian 


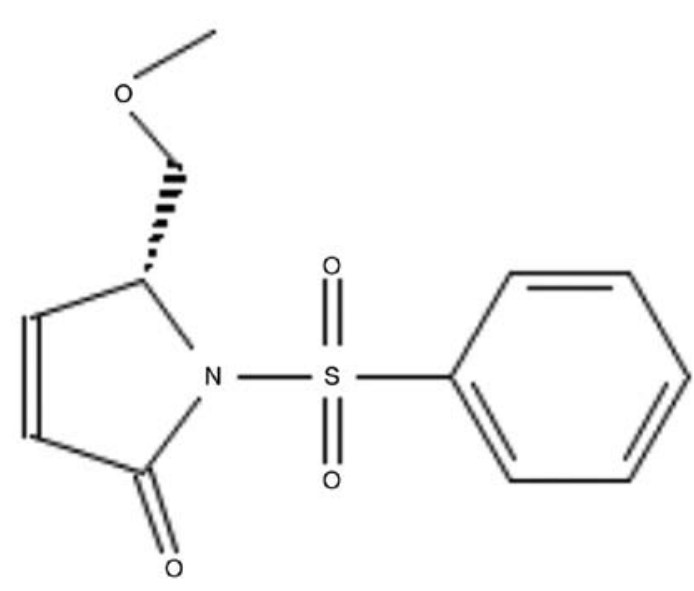

Figure 1. Chemical structure of CCL113.

Protein Extraction reagent (Thermo Fisher Scientific, Inc.) with a cocktail of protease inhibitor (Sigma-Aldrich; Merck $\mathrm{KGaA}$ ) and mixed gently for $10 \mathrm{~min}$. The cell lysates were centrifuged at $14,000 \times \mathrm{g}$ for $10 \mathrm{~min}$ at $4^{\circ} \mathrm{C}$. The Bio- $\mathrm{Rad}$ Protein Assay kit (Bio-Rad Laboratories, Inc.) was used to determine the protein concentration. Equal amounts $(50 \mu \mathrm{g})$ of extracted protein were resolved on $10 \%$ SDS-PAGE (ATTO Corporation) and transferred onto PVDF membranes (Trans-Blot Turbo $^{\text {TM }}$ Transfer Pack; Bio-Rad Laboratories, Inc.). The membranes were blocked with $5 \%$ skim milk for $1 \mathrm{~h}$ at room temperature and then probed at $4^{\circ} \mathrm{C}$ overnight with the following mouse monoclonal antibodies: Anti-p-histone H3 (Ser10) (1:1,1000; cat. no. 9706S; Cell Signaling Technology, Inc.), anti-histone H3 (1:1,1000; cat. no. 14269S; Cell Signaling Technology, Inc.), anti-cyclin B1 (1:2,000; cat. no. 4135S; Cell Signaling Technology, Inc.), anti-phosphorylated (p)-CDK1 (Tyr15) (1:1,1000; cat. no. 9111S; Cell Signaling Technology, Inc.), anti-p-CDK1 (Thr14) (1:1,000; cat. no. 2543S; Cell Signaling Technology, Inc.), anti-p-CDK1 (Thr161) (1:1,000; cat. no. 9114S; Cell Signaling Technology, Inc.), anti-CDK1 (1:1,000; cat. no. 9116S; Cell Signaling Technology, Inc.), anti-cyclin D1 (1:1,000; cat. no. 2922S; Cell Signaling Technology, Inc.), anti-CDK4 (1:1,000; cat. no. 2906; Cell Signaling Technology, Inc.), anti-cyclin E1 (1:1,000; cat. no. 4129T; Cell Signaling Technology, Inc.), anti-Cdc25B (1:1,000; cat. no. 9525S; Cell Signaling Technology, Inc.), anti-Cdc25C (1:1,000; cat. no. 9522; Cell Signaling Technology, Inc.), anti-p-Cdc25C (Thr48) (1:1,000; cat. no. 9527T; Cell Signaling Technology, Inc.), anti-Plk1 (1:500; cat. no. 4535S; Cell Signaling Technology, Inc.), anti-p-Plk1 (Thr210) (1:1,000; cat. no. 5472S; Cell Signaling Technology, Inc.), anti-CDK2 (1:200; cat. no. sc-6248; Santa Cruz Biotechnology, Inc.), anti-p-CDK2 (Thr160) (1:1,000; cat. no. 2561S; Cell Signaling Technology, Inc.), anti-ATM (1:1,000; cat. no. 92356S; Cell Signaling Technology, Inc.) anti-Chk2 (1:1,000; cat. no. 3440T; Cell Signaling Technology, Inc.), anti-p-Chk2 (Thr68) (1:1,000; cat. no. 2661S; Cell Signaling Technology, Inc.), anti-p-p53 (Ser15) (1:1,000; cat. no. 9286; Cell Signaling Technology, Inc.), anti-p21 (1:2,000; cat. no. 2946S; Cell Signaling Technology, Inc.), anti-poly (ADP-ribose) polymerase (PARP) (1:1,000; cat. no. 9542S; Cell Signaling Technology, Inc.), anti- $\beta$-actin $(1: 1,000$; cat. no. $3700 \mathrm{~S}$; Cell Signaling Technology, Inc.), anti-cyclin A $(1: 1,000$; cat. no. sc-239; Santa Cruz Biotechnology, Inc.), anti-p53 (1:1,000; cat. no. sc-126; Santa Cruz Biotechnology, Inc.) and p-ATM (Ser1981) (Cell Signaling Technology, Inc. \#4526S, dilution: 1:1,000). After washing three times with TBS, the blots were incubated with an HRP-linked anti-mouse IgG (1:1,000; cat. no. 7076S; Cell Signaling Technology, Inc.) for $1 \mathrm{~h}$ at room temperature. Clarity Western ECL substrate (Bio-Rad Laboratories, Inc.) was used to visualize protein signals. The bands were analyzed using ImageJ v1.46r software (National Institutes of Health).

Docking studies. The geometrical details of the $\alpha \beta$-tubulin protein were obtained from the Research Collaboratory for Structural Bioinformatics Protein Data Bank (https://www. rcsb.org) with the accession code 5syf (33). The structure was cleared of all solvent molecules and compounds before proceeding with the analysis. Docking analysis was performed separately for the $\alpha$ - and $\beta$-tubulin subunits. The 3D chemical structures of taxol and CCL113 were designed using Avogadro software (version 1.1.1) (https://avogadro.cc) (34) and optimized in Gaussian 16 (Gaussian Inc.) at the B3LYP/6-31G (d, p) theoretical level $(35,36)$. AutoDock 4.2 software (http://autodock. scripps.edu) (37) was used for molecular docking simulations. Structure files for proteins and ligands were made in the PDBQT format using default charges. Furthermore, non-polar hydrogen atoms were conjoined using AutoDockTools (version 1.5.6) (http://autodock.scripps.edu). A grid box with the dimensions $76 \AA$ x $76 \AA$ x $76 \AA$ XYZ was centered on the tubulin structure. A precalculated value for binding affinity for each ligand was prepared using AutoGrid 4.2 (http://autodock. scripps.edu), and rigid docking was accomplished using the Lamarckian genetic algorithm parameter (37). All other parameters in the AutoDock 4.2 software were considered in their default settings. The best pose for docking was selected based on the lowest values of binding energies obtained. The free binding energies were computed using the in-built linear regression model in AutoDock 4.2. The root-mean-square deviation (RMSD) values for ligands (with the dock input file) and the hydrogen bond occupancy were calculated using PyMOL (https://pymol.org/2/) (38).

Statistical analysis. All values were expressed as the mean \pm SD. Statistical analyses were performed using data obtained from three independent experiments. Data were analyzed using the Mann-Whitney U test with the software Statcel4 version 4 (OMS). One-way ANOVA followed by Bonferroni's correction were used for multiple comparisons. $\mathrm{P}<0.05$ was considered to indicate a statistically significant difference.

\section{Results}

Effects of CCL113 on cell viabilities. The anti-proliferative effects of the novel sulfonamide CCL113 was observed in HeLa and Vero cells during the anticancer drug screening of the Chiba Chemical Library. For the screening, cervical cancer-derived HeLa cells were chosen as a typical cancer cell line, in which wild-type p53 is expressed (39). Monkey kidney-derived Vero cells were chosen as a noncancerous cell line (40). CCL113 was one of the four compounds with an $\mathrm{IC}_{50}$ that was 10 -fold lower 


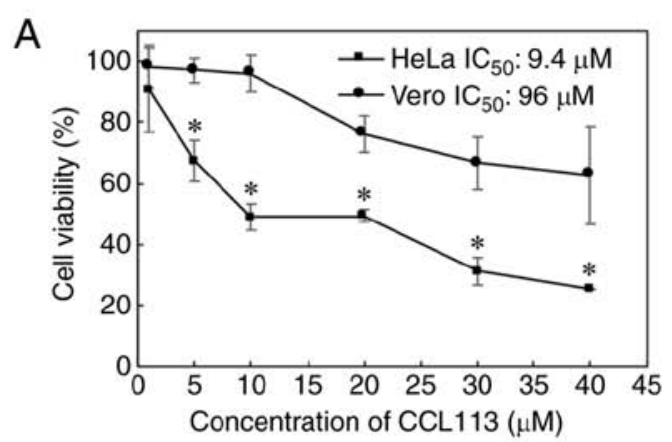

B
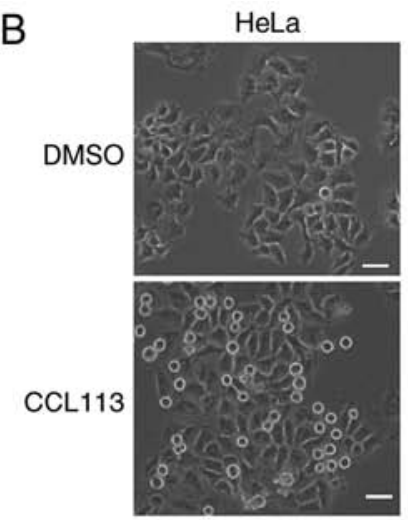
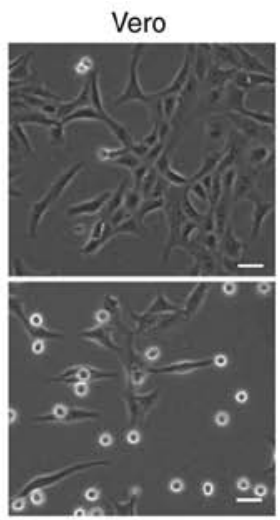

C

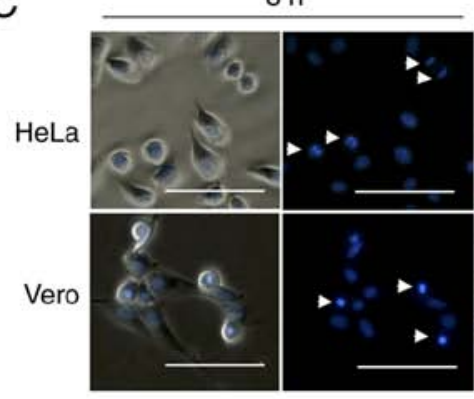

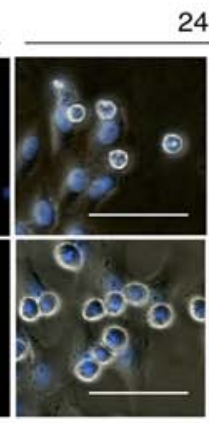

$24 \mathrm{~h}$

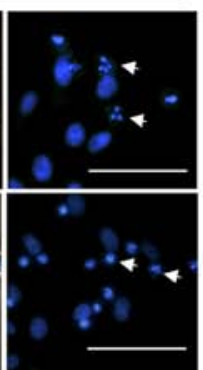

D

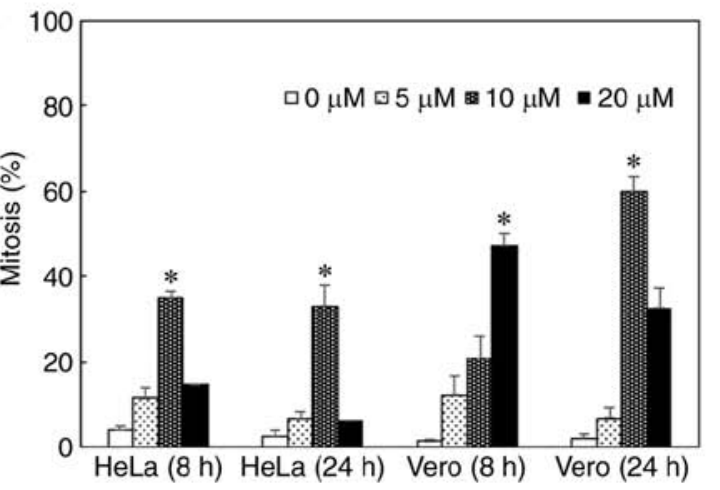

Figure 2. Effects of CCL113 on cell viability and morphology. (A) Inhibitory effects of CCL113 on the viability of HeLa and Vero cells after treatment with CCL113 at the indicated concentrations for $24 \mathrm{~h}$ were assessed by ATP assays. The differences in cell viability were analyzed using one-way ANOVA followed by Bonferroni's multiple comparison test. ${ }^{*} \mathrm{P}<0.05$. (B) Cell morphology after $24 \mathrm{~h}$ of treatment with $10 \mu \mathrm{M}$ CCL113. (C) Hoechst 33342 staining of cell nuclei and DNA in HeLa and Vero cells at 8 and $24 \mathrm{~h}$ post treatment with $10 \mu \mathrm{M}$ CCL113. Arrows indicate cells in prometaphase or metaphase at $8 \mathrm{~h}$ post treatment and cells with abnormal nuclei at $24 \mathrm{~h}$ post treatment. Scale bar represents $50 \mu \mathrm{m}$. (D) Mitotic indices of HeLa and Vero cells treated with DMSO or CCL113 at 8 and 24 h post-treatment. Values are presented as the mean \pm standard deviation. Data presented are the mean of three different fields and analyzed using one-way ANOVA followed by Bonferroni's multiple comparison test. " $\mathrm{P}<0.05$ vs. $0 \mu \mathrm{M}$.

for HeLa than for Vero cells. Further screening using HepG2 and TIG-1-20 showed only CCL113 exhibited cancer-cell specific cytotoxicities (data not shown). The cytotoxicity of CCL113 was assessed in HeLa and Vero cells using an ATP assay. The $\mathrm{IC}_{50}$ of CCL113 for HeLa and Vero cells was 9.4 and $96 \mu \mathrm{M}$, respectively. The results showed that the cell viability of HeLa, but not Vero cells, was significantly decreased following $24 \mathrm{~h}$ treatment with 5 and $10 \mu \mathrm{M}$ CCL113 (Fig. 2A). Significant differences in cytotoxicity were also observed between HeLa and Vero cells at 20-40 $\mu \mathrm{M}$, although CCL113 caused Vero cells cytotoxicity at concentrations of $>10 \mu \mathrm{M}$. Furthermore, the effects of 5-20 $\mu \mathrm{M}$ CCL113 on cell cycle progression in both cell lines were investigated. Both HeLa and Vero cells showed a marked increase in the number of round cells after $8 \mathrm{~h}$ of $10 \mu \mathrm{M}$ CCL113 treatment (Fig. 2B). Hoechst 33342 staining of cell nuclei indicated that by $8 \mathrm{~h}$, the chromosomes condensed and congregated to the equatorial plane, in a manner typical of cells in $\mathrm{M}$ phase in both HeLa and Vero cells. By $24 \mathrm{~h}$, abnormal nuclei were observed in mitotic HeLa cells (Fig. 2C). These observations suggested that CCL113 might induce cell cycle arrest in the $\mathrm{M}$ phase. Both cells showed an increased mitotic index after treatment with CCL113, and the effect was more evident in Vero cells (Fig. 2D).

Effects of CCL113 on cell cycle progression. To further verify CCL113-induced cell cycle arrest, CCL113-treated (10 $\mu \mathrm{M}$;
8 and 24 h) HeLa and Vero cells were analyzed by flow cytometry (Fig. 3A and B). Compared with control groups, a significantly higher proportion of CCL113-treated cells was observed in the $\mathrm{G}_{2} / \mathrm{M}$ phase (Fig. $3 \mathrm{C}$ and D). The results were consistent with the morphological observations.

Effects of CCL113 on the expression of cell cycle regulators. To elucidate the molecular basis of CCL113-induced M phase arrest in HeLa and Vero cells, the levels of cell cycle regulatory proteins were assessed using western blotting. Total cellular protein was isolated from cells treated with $10 \mu \mathrm{M}$ CCL113 for 8 and $24 \mathrm{~h}$. Since phosphorylation at Ser10 of histone H3 is significantly related to mitotic chromosome condensation (41-44), phosphorylation levels of histone H3 (Ser10) were first examined to confirm mitotic arrest. The results showed that the phosphorylation levels of histone H3 (Ser10) were significantly upregulated in CCL113-treated cells, suggesting that CCL113 induced M phase arrest by facilitating phosphorylation at Ser10 of histone H3 (Fig. 4A).

Activation of the CDK1-cyclin B1 complex initiates entry into mitosis and facilitates mitotic progression $(13,14)$. CDK1 activation, in turn, requires dephosphorylation at Tyr15 and Thr14 residues and phosphorylation at Thr161 (16). To investigate the activity of CDK1-cyclin B1, the levels of cyclin B1 and p-CDK1 in CCL113-treated HeLa and Vero cells were measured. As shown in Fig. 4A, the levels of 
A
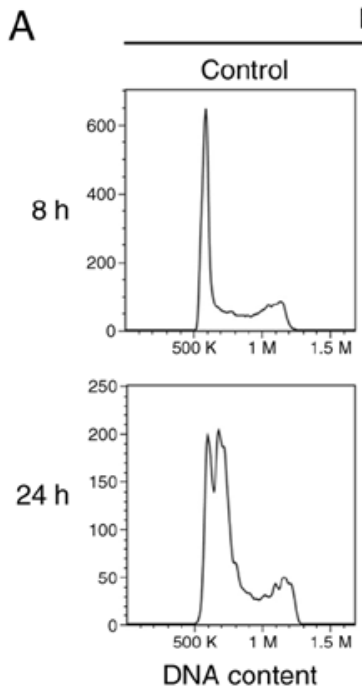

DNA content
HeLa
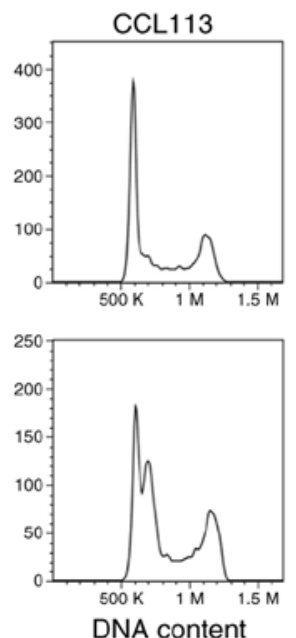

C

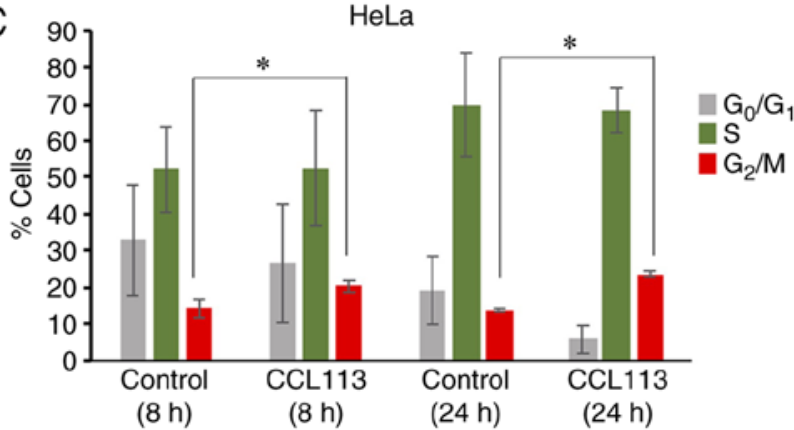

B

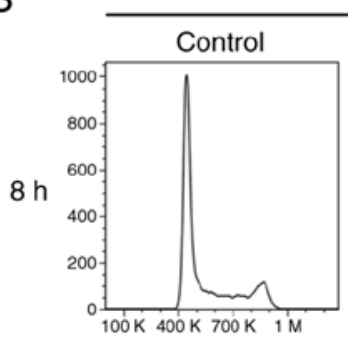

Vero
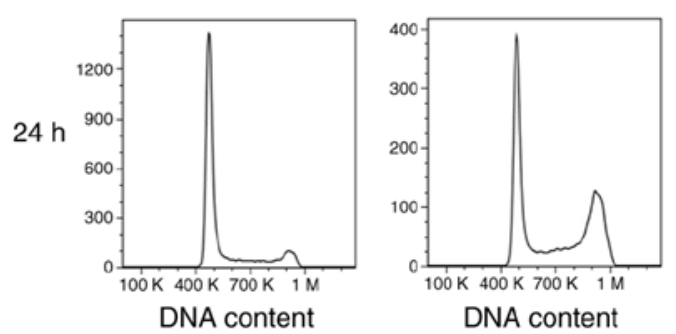

Vero

D

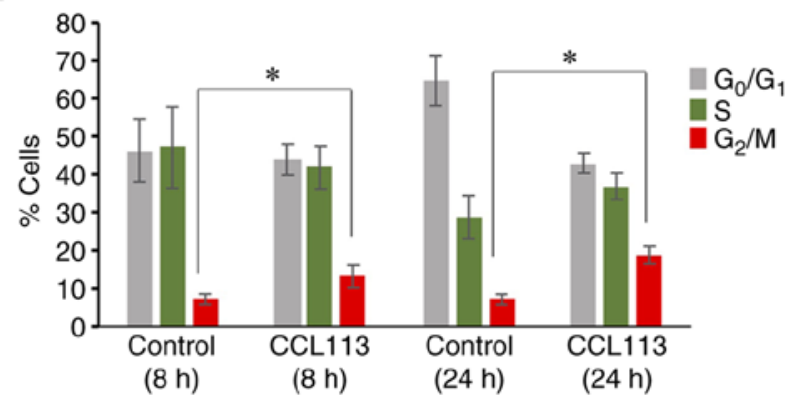

Figure 3. Effects of CCL113 on cell cycle progression. Flow cytometry analysis of control (DMSO-treated) and CCL113-treated (A) HeLa cells and (B) Vero cells

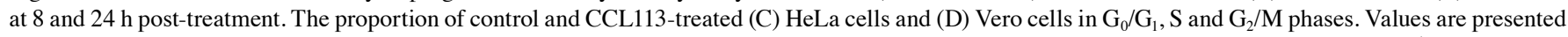
as the mean \pm standard deviation. Data presented are the mean of three independent experiments and analyzed using the Mann-Whitney $\mathrm{U}$ test. ${ }^{*} \mathrm{P}<0.05$.

cyclin B1 in CCL113-treated HeLa cells was significantly higher compared with DMSO-treated cells. This could be explained by the increase in the number of cells in $\mathrm{M}$ phase. As depicted in Fig. 4A, the results showed that in HeLa cells, the relative phosphorylation levels at Tyr15 and Thr14 [p-CDK1(Tyr15)/CDK1 and p-CDK1(Thr14)/CDK1] were significantly elevated at $8 \mathrm{~h}$, indicating an increase in CDK1 inhibitory phosphorylation. Additionally, in Vero cells, the relative phosphorylation levels at Tyr15 and Thr14 of CDK were significantly lower at $24 \mathrm{~h}$, indicating a relative decrease in the CDK1 inhibitory phosphorylation. CCL113-mediated inactivation of CDK1 by inhibitory phosphorylation at Tyr15 and Thr14 in HeLa cells might inhibit mitotic entry and progression, leading to an increase in the number of cells in the $G_{2} / M$ phase. By contrast, the elevated expression of cyclin $\mathrm{B} 1$ and decrease in CDK1 phosphorylation at Tyr15 and Thr14 in Vero cells (CCL113 treatment, $24 \mathrm{~h}$ ) could explain the increase in cells in $\mathrm{M}$ phase with activated CDK1-cyclin B1 complexes.

The Thr210 residue of Plk1 protein is the primary phosphorylation site responsible for its activation during mitosis; moreover, activated $\mathrm{P} 1 \mathrm{k} 1$ regulates the CDK1-cyclin $\mathrm{B} 1$ complex during mitosis $(32,45)$. Following treatment with CCL113, significantly increased Thr210 phosphorylation of Plk1 was observed in both HeLa and Vero cells, consistent with the increased number of cells in the $\mathrm{G}_{2} / \mathrm{M}$ phase (Fig. 4A).
Therefore, CCL113 treatment might inhibit the activation of CDK1 indirectly by upregulating Plk1.

Subsequently, the present study examined whether CCL113 affected the expression of regulatory proteins during other phases of the cell cycle, including key regulators of $G_{1}$ progression (cyclin D1 and CDK4), $\mathrm{G}_{1} / \mathrm{S}$ transition (cyclin E1 and $\mathrm{p}-\mathrm{CDK} 2$ ) and $\mathrm{S}$ phase progression (cyclin $\mathrm{A}$ and $\mathrm{p}-\mathrm{CDK} 2$ ). As shown in Fig. 4B, CCL113 had little effect on the expression of CDK 4 and cyclin E1, key regulators of $G_{1}$ and $G_{1} / S$ transition, at $8 \mathrm{~h}$. However, CCL113 significantly reduced the protein levels of cyclin D1 after $24 \mathrm{~h}$ of treatment, suggesting the decrease in the number of cells in the $G_{1}$ phase. Aside from a temporal upregulation of cyclin $\mathrm{A}$ in Vero cells after $8 \mathrm{~h}$, CCL113 seemed to have a negligible direct effect on the expression levels of cyclin A and p-CDK2 (Thr160) in both HeLa and Vero cells, suggesting CCL113 had little effect on $\mathrm{G}_{1} / \mathrm{S}$ transition. These results suggested that although CCL113 treatment led to a slight modulation in the regulatory proteins during other phases of the cell cycle, its main impact was observed during the $\mathrm{M}$ phase in treated cells.

Dose-dependent effects of CCL113 on the cell cycle. Cdc25 phosphatases activated by Plk1 are responsible for the dephosphorylation and activation of CDK1 (46). Cdc25 phosphatases include three different isoforms: Cdc25A, B and C (46). To examine the effects of CCL113 on the expression levels of 
A

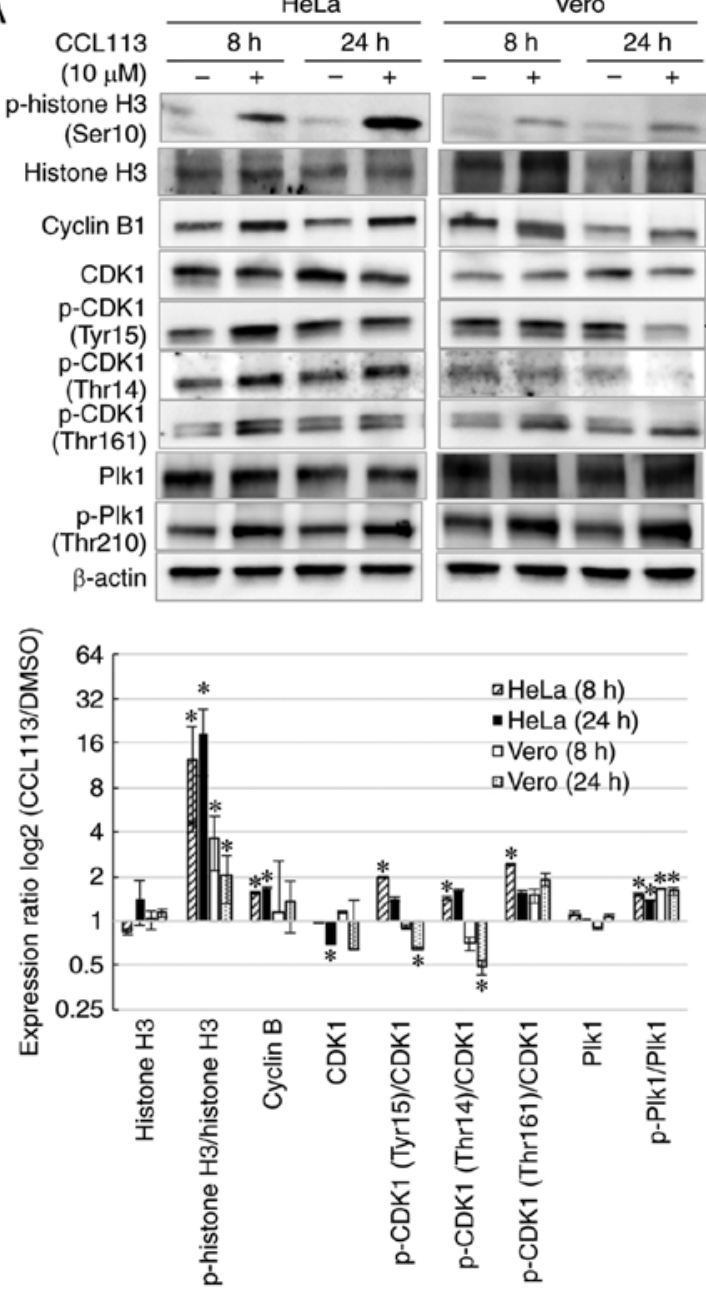

$\mathrm{B}$
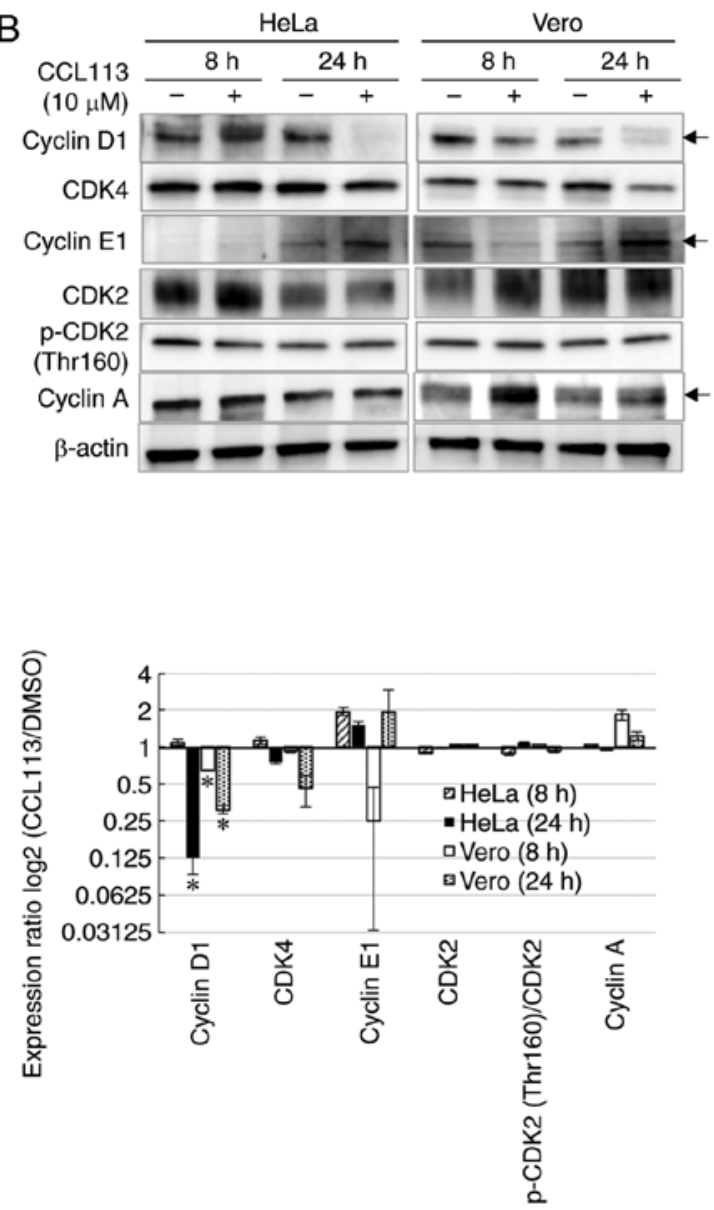

Figure 4. Western blot analyses of CCL113-treated HeLa and Vero cells. Total protein from CCL113-treated cells (+) or DMSO-treated cells (-) at 8 and $24 \mathrm{~h}$

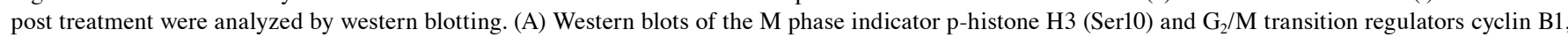
CDK1, p-CDK1 (Tyr15), p-CDK1 (Thr14), p-CDK1 (Thr161), and p-Plk1 (Thr210) from HeLa and Vero cells. (B) Western blots of the $\mathrm{G}_{1}$ regulators cyclin D1 and CDK4; the $\mathrm{G}_{1} / \mathrm{S}$ transition regulators cyclin E1 and p-CDK2 (Thr160); and the S regulator cyclin A in HeLa and Vero cells. Arrows indicate the positions of targeted proteins. $\beta$-actin was used as an internal control to show equivalent protein loading. Quantitative expression ratio (CCL113-treated/DMSO-treated) normalized to $\beta$-actin data is expressed as $\log _{2}$. Values are presented as the mean \pm standard deviation. Data were analyzed using the Mann-Whitney $\mathrm{U}$ test. ${ }^{*} \mathrm{P}<0.05$ vs. DMSO only treatment. Plk1, serine/threonine-protein kinase PLK1; p, phosphorylated.

Cdc25 and cell cycle progression, cells were treated with various concentrations $(0,5,10$ and $20 \mu \mathrm{M})$ of CCL113 and the levels of $\mathrm{Cdc} 25$ phosphatases were examined by western blotting. Nocodazole, an inducer of $\mathrm{M}$ phase arrest, served as a positive control.

In HeLa cells, the expression of p-histone H3 (Ser10) increased as the concentration of CCL113 increased from 5 to $10 \mu \mathrm{M}$ but decreased at $20 \mathrm{mM}$ (Fig. 5A), suggesting that in these cells, CCL113 might inhibit mitotic entry at $20 \mathrm{mM}$. The levels of Cdc25B and total Cdc25C protein decreased in HeLa cells in a time- and dose-dependent manner in response to CCL113 treatment (Fig. 5A). RT-qPCR analysis did not detect any apparent changes in $\mathrm{Cdc} 25 \mathrm{~B} / \mathrm{C}$ mRNA levels in HeLa cells after treatment with 5 to $20 \mu \mathrm{M}$ CCL113 for $8 \mathrm{~h}$ (data not shown). The levels of phosphorylated Plk1 (p-Plk1, Thr210) and p-histone H3 (Ser10) showed a similar response after treatment with various concentrations of CCL113 (Fig. 5A), indicating that 5 to $10 \mu \mathrm{M}$ CCL113 might inhibit mitotic progression but not mitotic entry. In addition, a reduced amount of actin in HeLa cells was observed following exposure to $20 \mu \mathrm{M}$ CCL113, suggesting that the cytotoxicity of $20 \mu \mathrm{M}$ CCL113 might cause nonspecific protein degradation.

As shown in Fig. 5B, Vero cells showed a similar expression pattern of p-histone $\mathrm{H} 3$ (Ser10) and $\mathrm{Cdc} 25 \mathrm{~B}$ protein in HeLa cells in response to treatment with various concentrations of CCL113.

Visualization of CCL113-induced cell cycle alterations in HeLa-Fucci and Vero-Fucci cells. The Fucci system, based on fluorescent ubiquitination-based cell cycle indicator (FUCCI), allows visualization of cell cycle progression in real time at the single-cell level, and the dynamic data can aid in understanding how individual cells respond to a drug (47). CCL113-induced cell cycle alterations in synchronized HeLa-Fucci and Vero-Fucci cells were monitored. FUCCI can be used to determine the distribution of a cell population through different stages of the cell cycle and distinguish $G_{1}$ and $S / G_{2} / M$ phases of the cell cycle by labeling $G_{1}$ nuclei in red and $S / G_{2} / M$ nuclei in green. During the $G_{1} / S$ transition (red-to-green conversion), red and green fluorescence overlap, resulting in yellow nuclei. 
A
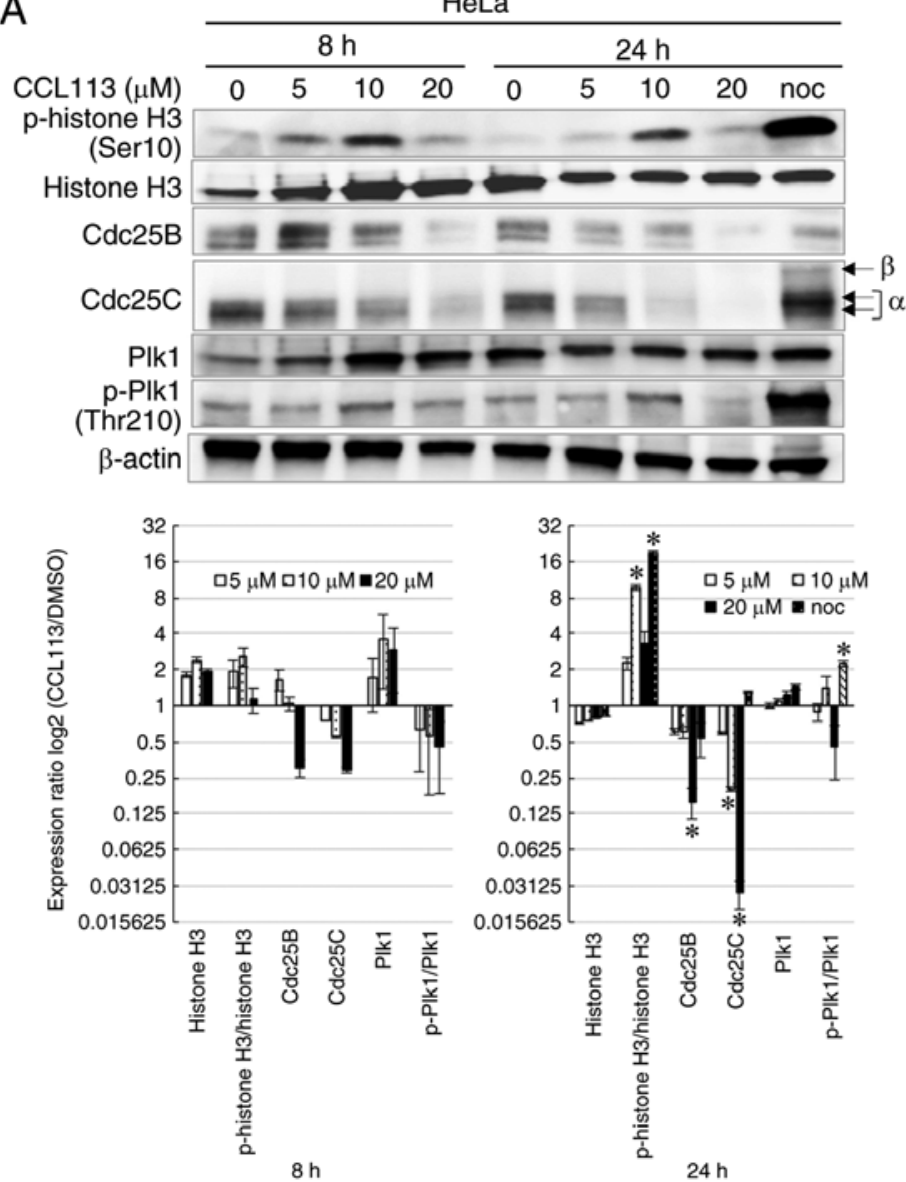
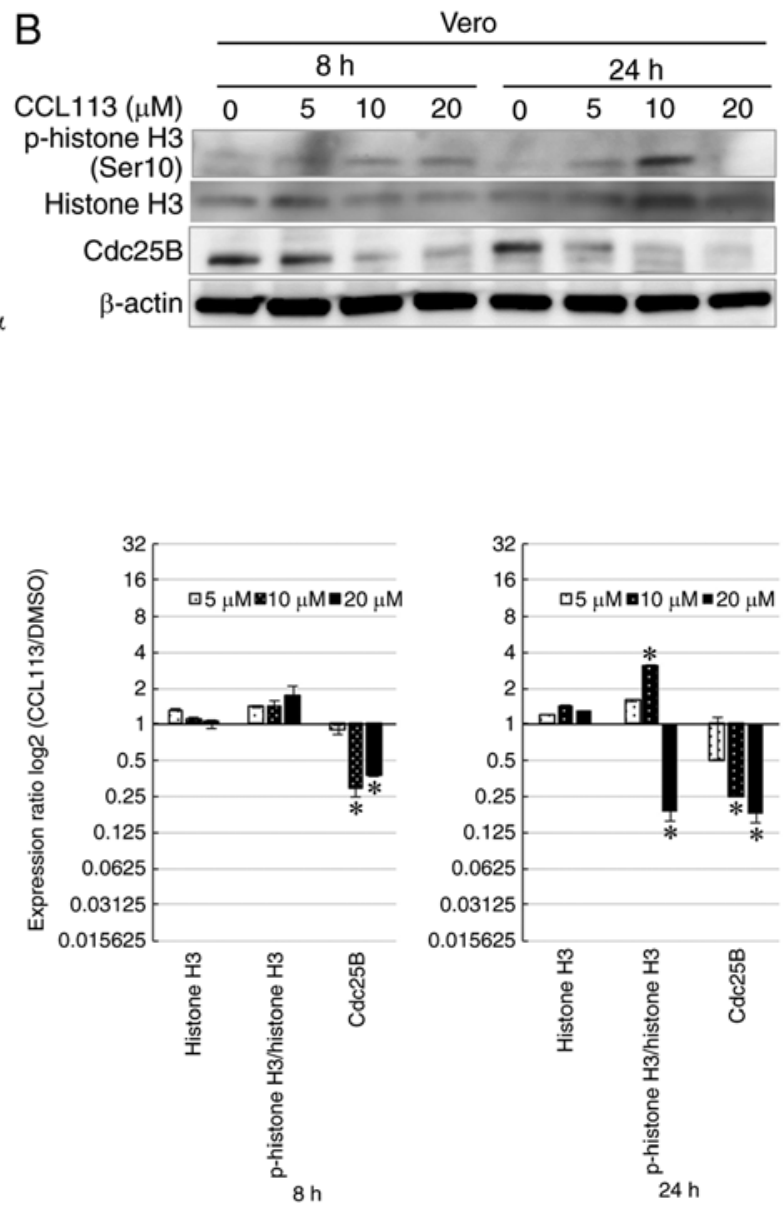

Figure 5. Dose-dependent effects of CCL113 on HeLa and Vero cells. Western blots of p-histone H3 (Ser10), Cdc25 phosphatases (Cdc25B/C) and p-Plk1 (Thr210) in (A) HeLa cells and of p-histone H3 (Ser10) and Cdc25B in (B) Vero cells are shown. ' $\alpha$ ' and ' $\beta$ ' indicate the position of the 'interphasic' forms and mitotic form of $\mathrm{Cdc} 25 \mathrm{C}$, respectively. $\beta$-actin was used as an internal control to show equivalent protein loading. Quantitative expression ratio ( 5,10 and $20 \mu \mathrm{M}$-treated/ $\mu \mathrm{M}$-treated) normalized to $\beta$-actin is expressed as $\log _{2}$. Values are presented as the mean \pm standard deviation. Data were analyzed using one-way ANOVA followed by Bonferroni's multiple comparison test. ${ }^{*} \mathrm{P}<0.05$ vs. $0 \mu \mathrm{M}$. noc, $0.5 \mu \mathrm{M}$ nocodazole; Plk1, serine/threonine-protein kinase PLK1; p, phosphorylated.

The results showed that most HeLa-Fucci and Vero-Fucci cells were in the $\mathrm{S}$ phase at the beginning of imaging (Fig. 6A and B) and showed differential progression following exposure to CCL113. The serially collected images of 650 HeLa-Fucci and 344 Vero-Fucci cells were traced and analyzed. In synchronized HeLa-Fucci cells, 19\% of cells required more time than control cells to progress through the $M$ phase (mean, 2.4 vs. $1.6 \mathrm{~h}$ for control cells) and passed through the $\mathrm{G}_{1}$ phase to $\mathrm{S} / \mathrm{G}_{2}$ phase as shown in Fig. $6 \mathrm{~A}-\mathrm{a}$. A total of $24 \%$ of cells underwent abnormal cell division and subsequent cell death at the $\mathrm{G}_{1}$ phase (Fig. 6A-b). These cells required more time to progress through the $\mathrm{M}$ phase (mean, $4.0 \mathrm{~h}$ ) than the control cells. As shown in Fig. 6A-c, 53\% of cells entered the M phase and exhibited long-term mitotic cell rounding (mean, $16.6 \mathrm{~h}$ ) before eventual cell death. The nuclei of very few HeLa-Fucci cells $(1 \%)$ changed color from green to $\mathrm{G}_{1}$-like red without undergoing mitosis (Fig. 6A-d), while a few cells (3\%) were arrested at the $S / G_{2}$ phase and subsequently exhibited cell death (Fig. 6A-e). Therefore, CCL113 treatment resulted in a longer $S / G_{2}$ and $M$ phase in HeLa cells compared with control cells.

In contrast to HeLa-Fucci cells, Vero-Fucci cells exhibited different responses to CCL113. Nearly half the cells (48\%) progressed through the $S / G_{2}$ phase at approximately the same time (mean, $6.2 \mathrm{~h}$ ) as synchronized control cells but were arrested in the $\mathrm{M}$ phase (Fig. 6B-f). A total of $12 \%$ of treated cells required more time to progress through the $S / G_{2}$ phase (mean, $9.8 \mathrm{~h}$ ) and underwent prolonged mitosis (mean, $10.2 \mathrm{~h}$ ) to the $\mathrm{G}_{1}$-like phase without cytokinesis (Fig. 6B-g). Furthermore, $36 \%$ of cells progressed slowly through the $S / G_{2}$ phase (mean, $20.8 \mathrm{~h}$ ) and entered the $\mathrm{G}_{1}$-like phase without undergoing mitosis (Fig. 6B-h). Prior to transitioning to the $\mathrm{G}_{1}$-like phase, the nuclei of these cells stained yellow for a brief period, similar to $\mathrm{G}_{1} / \mathrm{S}$ transition (red-to-green conversion), suggesting that the $\mathrm{G}_{1}$-like phase did not correspond to the beginning of $\mathrm{G}_{1}$ phase, at which the red color is weak.

As shown in Fig. 6B-i, the 4\% of CCL113-treated Vero-Fucci cells that required a shorter time to progress through the $\mathrm{S} / \mathrm{G}_{2}$ phase than the control cells (mean, 2.3 vs. $5.6 \mathrm{~h}$ for control cells) underwent normal division. A small fraction of the Vero cell population may have experienced inefficient thymidine block, which reflected the cell population in the $\mathrm{G}_{2}$ phase and suggested that CCL113 may not be effective during the $G_{2}$ phase. To confirm and validate the cell cycle phase regulated by CCL113, CCL113-treated Vero-Fucci cells were further analyzed. As shown in Fig. 6C, CCL113 treatment significantly reduced the number of cells 1 to $1.5 \mathrm{~h}$ before $\mathrm{M}$ phase entry. Treament with CCL113 increased the number of cells with extended periods 
A

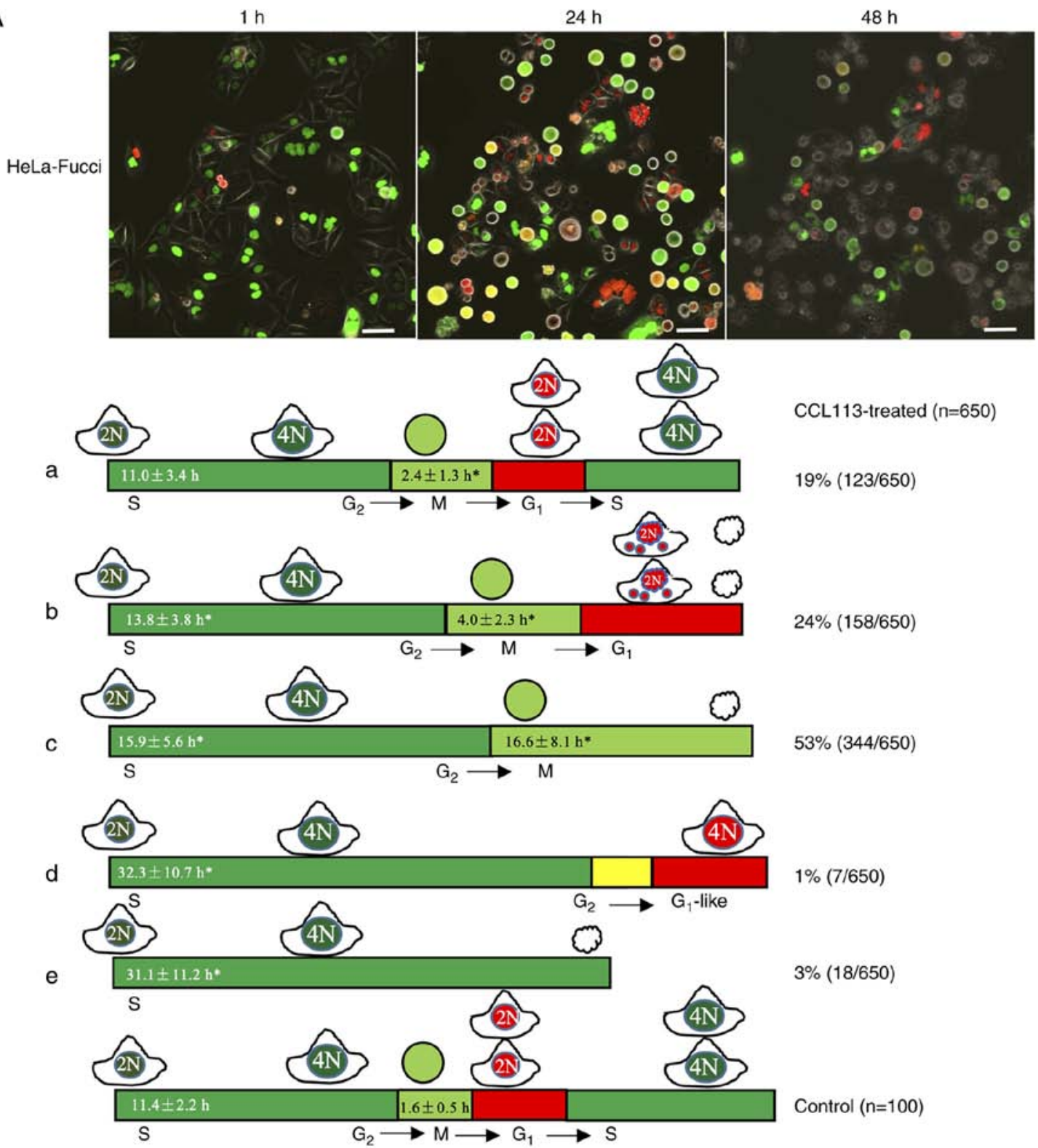

Figure 6. Continued.

before $M$ phase entry, suggesting that the $G_{2} / M$ checkpoint hindered the cells from entering the $\mathrm{M}$ phase.

Effects of CCL113 on DNA damage response and apoptosis. Cells that fail to progress through mitosis accumulate de novo DNA damage foci and experience mitotic failure $(23,48)$. To confirm whether CCL113 activated the DNA damage response, its central regulators, such as ATM and other proteins including $\mathrm{Chk} 2$, p53, and p21, were examined in cells treated with CCL113. The results showed that exposure to CCL113 $(10 \mu \mathrm{M})$ increased the levels of p-ATM (Ser1981), p-Chk2 (Thr68), p53 (Ser15), and p21 in HeLa cells (Fig. 7). Increase in p-p53 at Ser15 reduces the interaction with $\mathrm{E} 3$ ubiquitin-protein ligase MDM2 (49), which might explain the increase in p53 levels in CCL113-treated Vero cells (Fig. 7). To examine the effects of CCL113 on apoptosis, the present study analyzed the expression of PARP fragment, which is an indicator of apoptosis (10). Cleaved PARP fragment (89 kDa) was observed in CCL113-treated HeLa cells at 24 h (Fig. 7), indicating the induction of apoptosis; however, the cleaved PARP band could not be detected in CCL113-treated Vero cells at $24 \mathrm{~h}$, suggesting that CCL113-induced apoptosis might not be frequent in normal cells.

Effects of CCL113 on cell cycle progression in HepG2 cells and normal human fibroblasts. To investigate the effects of CCL113 on other cancer cells and normal cells, HepG2, a human liver cancer cell line, and TIG-1-20, normal human fibroblasts, were employed. Similar to HeLa cells, HepG2 cells are known to express wild-type p53 (39). Consistent with the results observed in HeLa and Vero cells, both HepG2 and TIG-1-20 cells showed a marked increase in the number of round cells after $24 \mathrm{~h}$ of exposure to $10 \mu \mathrm{M}$ CCL113. Hoechst 33342 staining of cell nuclei confirmed that CCL113 treatment arrested HepG2 cells in metaphase, whereas TIG-1-20 cells 
B
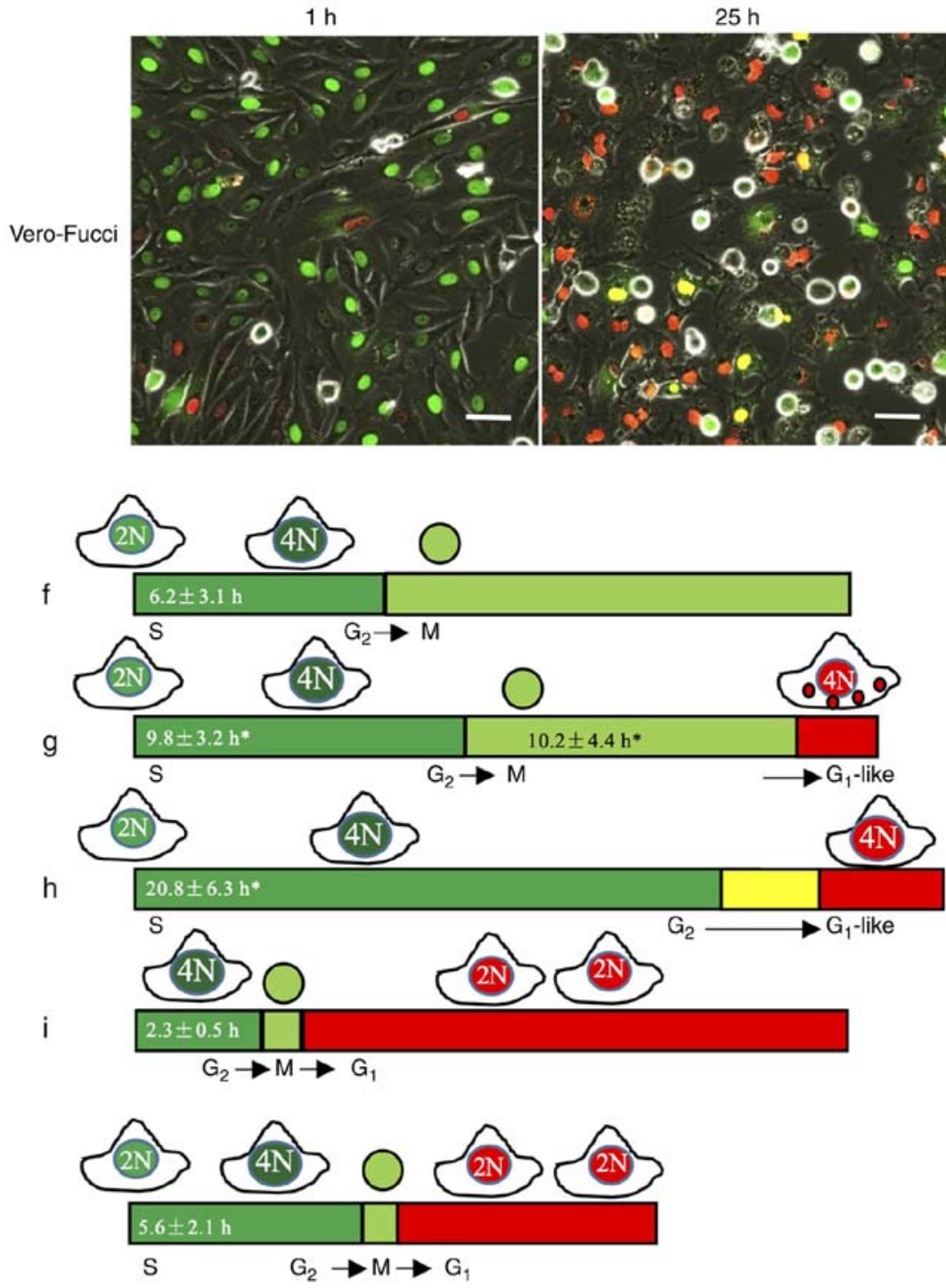

C

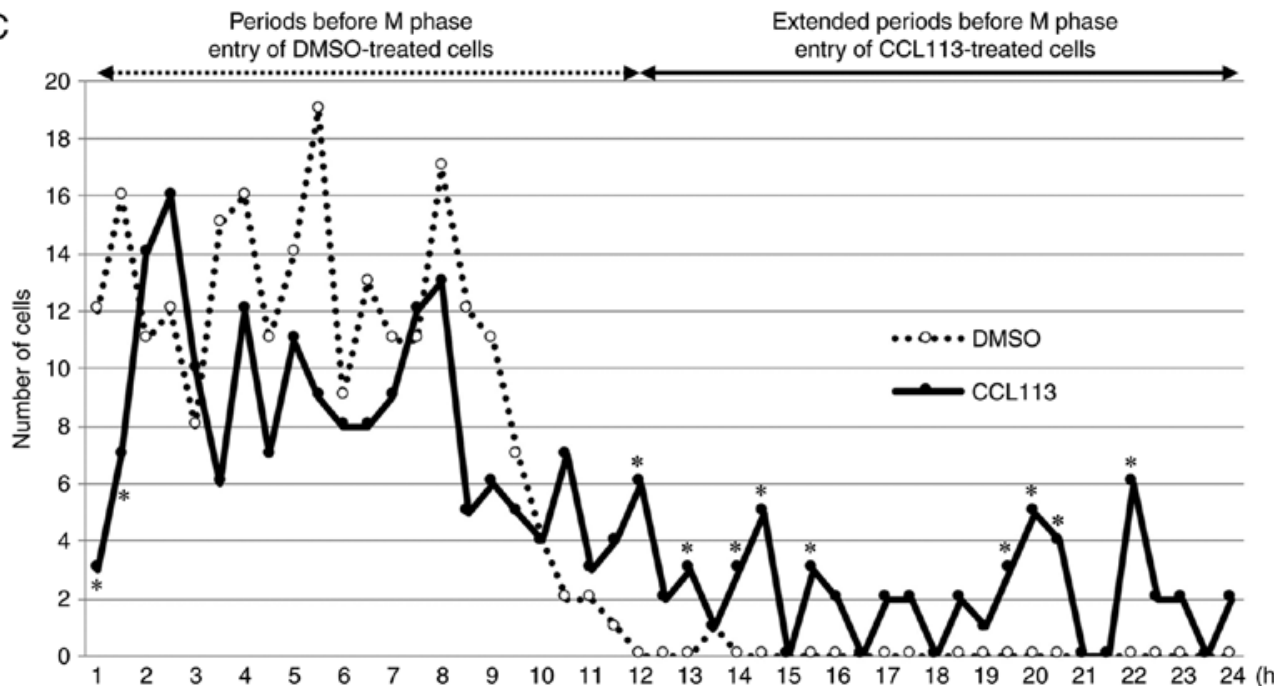

CCL113-treated $(n=344)$

$48 \%(166 / 344)$

$12 \%(40 / 344)$

$36 \%(125 / 344)$

$4 \%(13 / 344)$

Control $(n=132)$

Figure 6. Continued. CCL113-induced cell cycle alterations in HeLa-Fucci and Vero-Fucci cells. Fucci cells were synchronized at the G $\mathrm{G}_{1} / \mathrm{S}$ boundary by double thymidine blocking. Subsequently, cells were released and exposed to $10 \mu \mathrm{M}$ CCL113. Images of (A) HeLa-Fucci and (B) Vero-Fucci cells were obtained at 30-min intervals with a computer-assisted fluorescence microscope. High-magnification images of (a-e) six HeLa-Fucci cells and (f-j) four Vero-Fucci cells were selected as representative images. Boxes represent the duration of the $\mathrm{G}_{1}$ phase (red), $\mathrm{S} / \mathrm{G}_{2}$ phase (green), $\mathrm{M}$ phase (light green) and $\mathrm{G}_{2} / \mathrm{G}_{1}$-like transition (yellow) for each image. $2 \mathrm{~N}$ and $4 \mathrm{~N}$ represent diploid and tetraploid, respectively. The average duration of the $\mathrm{G}_{2}$ phase or $\mathrm{M}$ phase is shown. Scale bar represents $50 \mu \mathrm{m}$. Values are presented as the mean \pm standard deviation. Data were analyzed using the Mann-Whitney U test. (C) Effects of CCL113 on the periods before the M phase of unsynchronized Vero-Fucci cells. Unsynchronized Vero-Fucci cells were exposed to $10 \mu \mathrm{M}$ CCL113 or DMSO and imaged every $30 \mathrm{~min}$ for $24 \mathrm{~h}$. The distribution of the periods (h) between exposure to reagent and entry of 235 cells into mitosis was plotted. Data were analyzed using one-way ANOVA. ${ }^{*} \mathrm{P}<0.05$ vs. DMSO only treatment. 
Table I. Docking scores of CCL113 with the taxol-binding sites of $\alpha$ - and $\beta$-tubulin.

\begin{tabular}{lccc}
\hline Compounds (Tubulins) & CCL113 $(\alpha$-tubulin) & CCL113 $(\beta$-tubulin) & Taxol $(\beta$-tubulin) \\
\hline Free binding energy (kcal/mol) & -3.41 & -4.24 & -4.81 \\
RMSD & 1.52 & 0.80 & 2.18 \\
Hydrogen bond (H-bond) & 3 & 3 & 2 \\
\hline
\end{tabular}

RMSD, root-mean-square deviation.
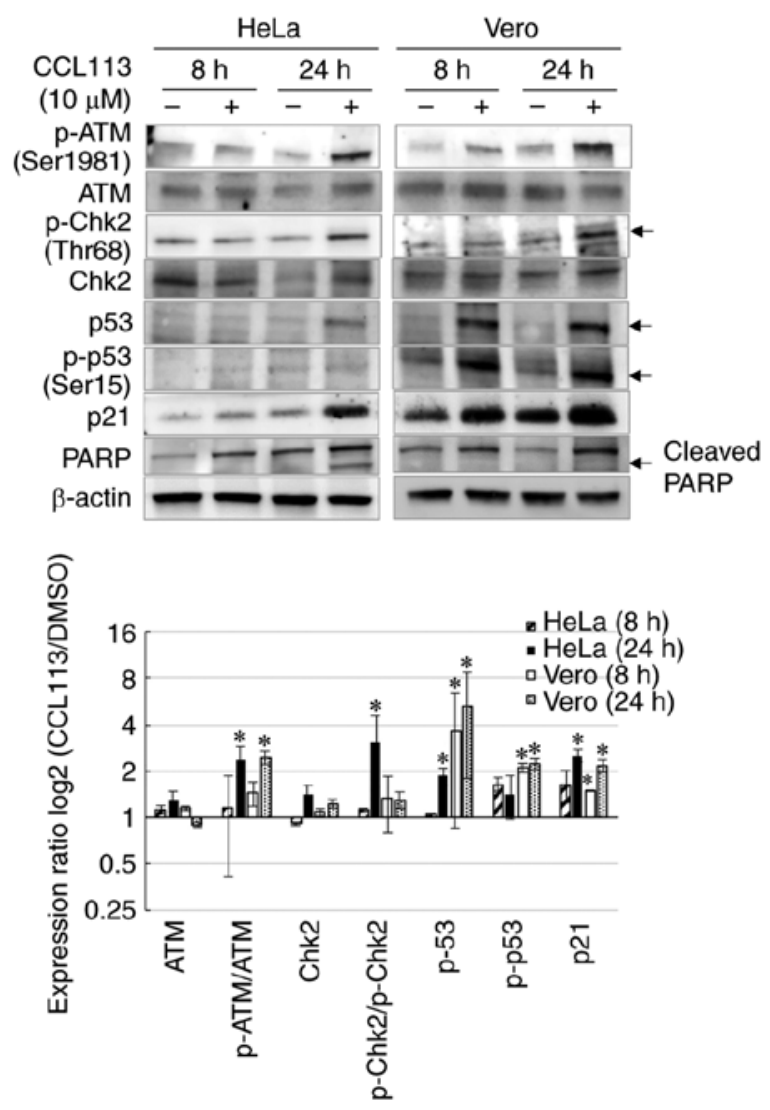

Figure 7. Effects of CCL113 on DNA damage response and apoptosis. Western blots of proteins associated with DNA damage response, including p-ATM (Ser1981), p-Chk2 (Thr68), p53, p-p53 (Ser15) and p21, and the apoptosis indicator PARP are shown for HeLa and Vero cells. Arrows indicate the positions of targeted proteins. $\beta$-actin was used as an internal control to show equivalent protein loading. The quantitative expression ratio (CCL113-treated/DMSO-treated) normalized to $\beta$-actin is expressed as $\log _{2}$. Values are presented as the mean \pm standard deviation. Data were analyzed using the Mann-Whitney U test ${ }^{*} \mathrm{P}<0.05$ vs. DMSO only treatment. Chk2, serine/threonine-protein kinase Chk2; PARP, poly (ADP-ribose) polymerase.

were arrested in prometaphase (Fig. 8A). Flow cytometry analyses showed that the number of both HepG2 and TIG-1-20 cells significantly increased in the $\mathrm{G}_{2} / \mathrm{M}$ phase following CCL113 treatment (Fig. 8B). Treatment with CCL113 significantly decreased the cell viability of HepG2 compared with TIG-1-20 cells, after $24 \mathrm{~h}$ of treatment (Fig. 8C).

As shown in Fig. 8D, the expression of cell cycle regulators in HepG2 cells in response to CCL113 treatment was comparable to the response observed in HeLa cells; the levels of cyclin B1 and phosphorylation of CDK1 at Tyr15 significantly increased, while the levels of Cdc25B and Cdc25C protein were decreased. Similarly, CCL113-treated TIG-1-20 cells showed responses comparable to those of Vero cells. Furthermore, CCL113 treatment led to a significant increase in the levels of p53 and p21 in HepG2 and TIG-1-20 cells. Meanwhile, the cleaved PARP fragment was observed only in CCL113-treated HepG2 cells and not in TIG-1-20 cells at $24 \mathrm{~h}$ (Fig. 8D), suggesting that apoptosis was induced only in HepG2 cells and not in normal cells, consistent with the results observed in HeLa and Vero cells.

Docking studies of CCL113 with $a$ - and $\beta$-tubulin. Since microtubule-targeting agents (MTAs), which are commonly used anticancer drugs, often function by blocking cell entry into mitosis $(50,51)$ the possibility of CCL113 acting as an MTA was investigated. Molecular docking studies between CCL113 and tubulins were performed using AutoDock 4.2. CCL113 exhibited the highest binding affinity at the taxol-binding site of $\beta$-tubulin (Table I). The free binding energy of CCL113 at the taxol-binding site of $\beta$-tubulin (-4.24) was favorable to facilitate the interaction, unlike that of a-tubulin and taxol (-3.41 and -4.81 , respectively). The RMSD value of CCL113 with b-tubulin was lower compared with taxol with $\beta$-tubulin. Furthermore, CCL113 exhibited a higher number of hydrogen bond interactions with the taxol-binding sites of $\beta$-tubulin than taxol, suggesting that CCL113 could bind to the taxol-binding site of $\beta$-tubulin.

\section{Discussion}

In HeLa cells, $>1,000$ proteins are reported to exhibit enhanced phosphorylation during mitosis, and most of them are expected to be CDK1 substrates (52). The CDK1-cyclin B1 complex plays a crucial role in mitotic entry and progression $(13,14)$, and its activity is regulated by CDK1-mediated phosphorylation at Tyr15 and Thr14 residues, while Cdc25 phosphatases are responsible for the dephosphorylation of these sites $(16,17)$. The present study identified a novel sulfonamide, CCL113, that resulted in cell cycle arrest in the $M$ phase and induced apoptosis in cancer cells, but not in normal cells. The effects of CCL113 on cell cycle regulatory proteins were similar in cancer and noncancerous cells. However, the consequence of these effects was cell death in HeLa cells, but not in Vero cells. Although these cell lines are from different origins and future studies should test CCL113 in additional cell lines, these differential effects mediated by CCL113 were possibly achieved by inhibition of $\mathrm{Cdc} 25$ protein via induction of the DNA damage response, suppression of CDK1-cyclin B activity, a prolonged $G_{2}$ phase at the $G_{2} / M$ checkpoint and cell cycle arrest in the $\mathrm{M}$ phase. 

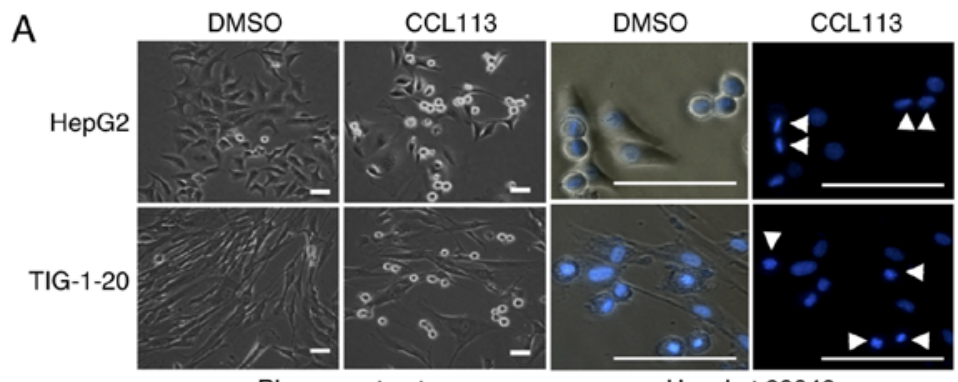

Phase contrast

Hoechst 33342
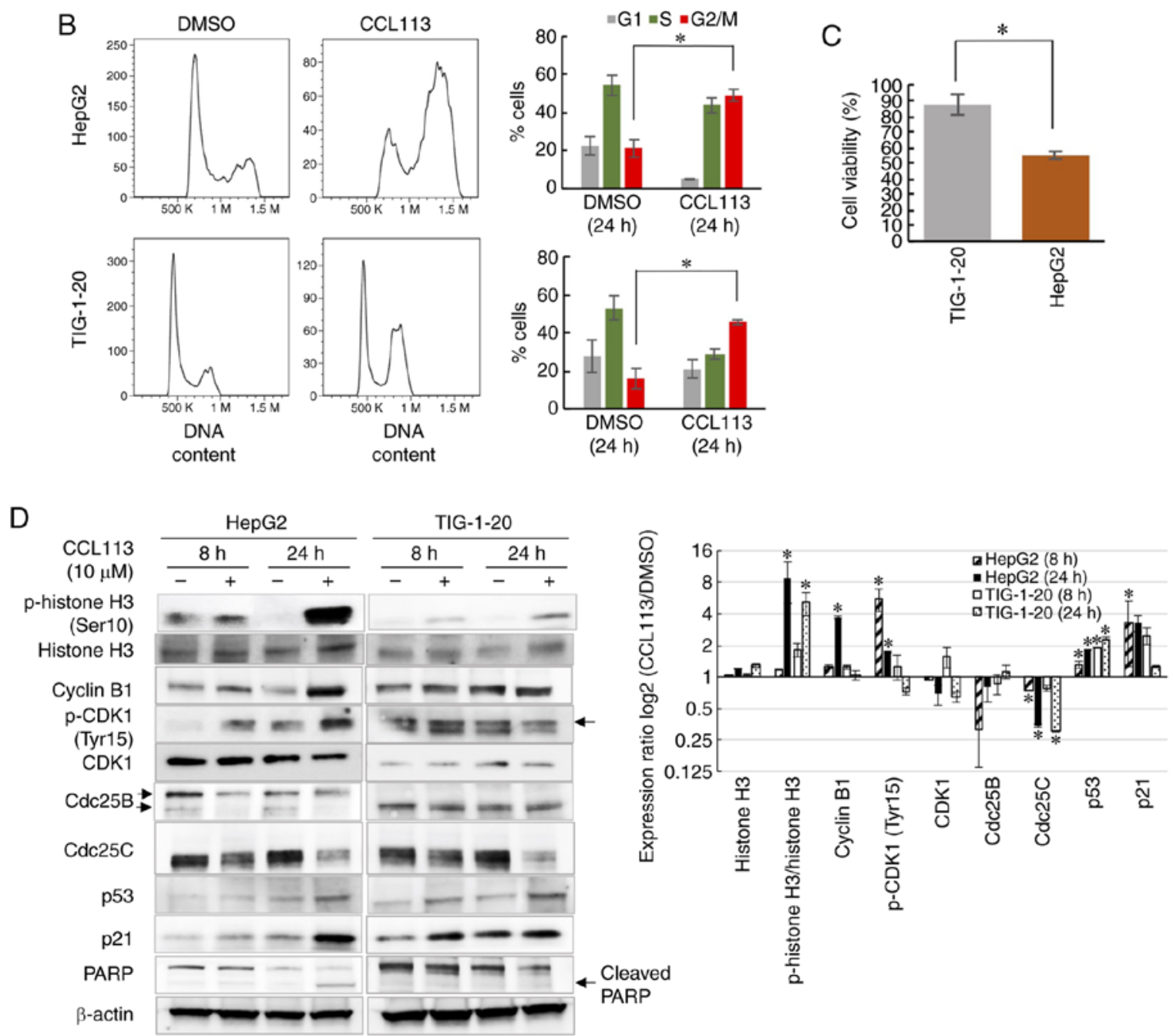

Figure 8. Effects of CCL113 on cell viability, morphology and cell cycle progression in HepG2 and TIG-1-20 cells. (A) Cell morphology after $24 \mathrm{~h}$ of treatment with $10 \mu \mathrm{M}$ CCL113. Hoechst 33342 staining of cell nuclei and DNA in HepG2 and TIG-1-20 cells at 8 h post-treatment with $10 \mu$ M CCL113. Arrows indicate cells in prometaphase or metaphase at $8 \mathrm{~h}$ post treatment. Scale bar represents $50 \mu \mathrm{m}$. (B) Flow cytometry analysis of control (DMSO-treated) and CCL113-treated HepG2 and TIG-1-20 cells at $24 \mathrm{~h}$ post treatment. (C) The viabilities of HepG2 and TIG-1-20 cells after treatment with $10 \mu \mathrm{M}$ CCL113 for $24 \mathrm{~h}$. (D) Western blot analyses of CCL113-treated HepG2 and TIG-1-20 cells. Total protein from $10 \mu \mathrm{M}$ CCL113-treated cells (+) or DMSO-treated cells (-) at 8 and $24 \mathrm{~h}$ post treatment in HepG2 and TIG-1-20 cells were subjected to western blotting using the indicated antibodies. Arrows indicate the positions of targeted proteins. $\beta$-actin was used as an internal control to show equivalent protein loading. The quantitative expression ratio (CCL113-treated/DMSO-treated) normalized to $\beta$-actin is expressed as $\log _{2}$. Values are presented as the mean \pm standard deviation. Data were analyzed using the Mann-Whitney $\mathrm{U}$ test. ${ }^{*} \mathrm{P}<0.05$ vs. DMSO only treatment. PARP, poly (ADP-ribose) polymerase.

Activation of the CDK1-cyclin B complex is regulated by several feedback loops involving Myt1, Wee1, Cdc25A/B/C, Plk1 and the Bora-Aurora-Plk1 complex (15). CDK1 is rendered inactive by the phosphorylation of Tyr15 and Thr14 by Myt1 and Wee1 kinases (15). Although relatively low CDK1-cyclin B activity is required to enter mitosis and some of these feedback loops may even be redundant, full activation of multiple feedback loops is essential for successful completion of a mitotic cycle $(14,15)$. For instance, the present results showed that CCL113-induced reduction of $\mathrm{Cdc} 25$ prolonged the $\mathrm{G}_{2}$ phase at the $\mathrm{G}_{2} / \mathrm{M}$ checkpoint but did not block mitotic entry, while lower levels of Cdc25 phosphatases were sufficient to block the completion of mitosis. 
Cdc25 phosphatases are critical regulators of the cell cycle and are required to control CDK dephosphorylation and activation (15). The expression and activity of $\mathrm{Cdc} 25$ are regulated by numerous mechanisms, such as cell cycle-controlled phosphorylation-dephosphorylation, transcription, post-translational regulation and protein degradation (15). In the present study, since the mRNA levels of Cdc25 were not affected by CCL113 treatment, the inhibition of $\mathrm{Cdc} 25$ was most likely due to protein degradation rather than transcriptional regulation. Since CCL113 activates the DNA damage response, which in turn promotes Cdc25 turnover, inhibition of $\mathrm{Cdc} 25$ could also be a result of indirect regulation by CCL113. Furthermore, the possible interaction of CCL113 at the taxol-binding site of b-tubulin might interfere with microtubule dynamics causing prolonged mitosis, which can lead to DNA damage and p53 induction (53).

The terminal cell cycle exit in the $\mathrm{G}_{2}$ phase is dependent on the induction of p53 and p21, resulting in the nuclear retention of cyclin B1 and the activation of APC/C $\mathrm{C}^{\mathrm{cdh} 1}(19-21)$. In the present study, significantly elevated levels of p53 and p21 were detected in noncancerous cells $8 \mathrm{~h}$ after CCL113 treatment. Meanwhile, FUCCI analyses revealed that CCL113-treated Vero cells could transition to the $G_{1}$-like phase from prolonged $G_{2}$ and $M$ phase with the degradation of Geminin (Fucci red), the $\mathrm{S} / \mathrm{G}_{2} / \mathrm{M}$ marker, which is a target of $\mathrm{APC} / \mathrm{C}^{\mathrm{cdh} 1}$. These results suggested that noncancerous cells could exit the cell cycle in response to CCL113 treatment and may explain why apoptosis was not observed in Vero and TIG-1-20 cells. In cancer cell lines with compromised p21 function, its induction is delayed, and cells are unable to terminally exit the cell cycle (2). In CCL113-treated HeLa and HepG2 cells, a significant increase in p53 and p21 levels was detected at $24 \mathrm{~h}$. FUCCI analyses revealed that very few CCL113-treated HeLa cells could exit the cell cycle, and most of the cells underwent mitotic arrest followed by apoptosis.

DNA damage response arrests the cell cycle to initiate DNA repair and prevent the proliferation of potentially unstable cells by promoting cell cycle exit (21). However, CCL113-treated cancer cells with compromised p21 function are unable to exit the cell cycle and undergo apoptosis (21). The docking study showed that CCL113 might act similarly to taxol, which disrupts mitosis. Although the mechanisms by which anticancer drugs that disrupt the cell cycle and then induce apoptosis are poorly understood, the present study showed that mitotic stress induced by these drugs might trigger DNA damage response.

In summary, the novel sulfonamide CCL113 was identified as a candidate anticancer drug by screening a chemical compound library. Although the widespread use of CCL113 may be restricted due to its cytotoxicity, this compound may serve as a lead compound for development of a more potent drug. The present results suggested that CCL113 induces apoptosis in cancer cells and cell cycle exit in noncancerous cells. These effects of CCL113 are presumably mediated by upregulation of the DNA damage response. Results of the docking analysis suggested the possible interaction of CCL113 with the taxol-binding site of $\beta$-tubulin, which can facilitate mitotic arrest and DNA damage and induce p53 induction.

\section{Acknowledgements}

We thank Dr Takayoshi Arai (Molecular Chirality Research Center, Department of Chemistry, Graduate School of
Science, Chiba University) for the generous donation of all the compounds from the Chiba Chemical Library.

\section{Funding}

This work was supported by JSPS KAKENHI (grant no. JP26430155).

\section{Availability of data and materials}

The datasets used and/or analyzed during the current study are available from the corresponding author on reasonable request.

\section{Authors' contributions}

RY, YO, KS and HS designed the study. RY and XM performed most of the experiments. RY and YO screened the chemical library, which was provided by AS, KY, SH, YT and AN. RY, ZT, SG, WC, NNW, QL, MV, KS, NI and SN analyzed the data. RY and HS wrote the manuscript. All authors read and approved the final manuscript.

\section{Ethics approval and consent to participate}

Not applicable.

\section{Patient consent for publication}

Not applicable.

\section{Competing interests}

The authors declare that they have no competing interests.

\section{References}

1. Malumbres $\mathrm{M}$ and Barbacid M: Cell cycle, CDKs and cancer: A changing paradigm. Nat Rev Cancer 9: 153-166, 2009.

2. Sherr CJ: Cancer cell cycles. Science 274: 1672-1677, 1996.

3. Cicenas $\mathrm{J}$ and Valius M: The CDK inhibitors in cancer research and therapy. J Cancer Res Clin Oncol 137: 1409-1418, 2011.

4. Diaz-Moralli S, Tarrado-Castellarnau M, Miranda A and Cascante M: Targeting cell cycle regulation in cancer therapy. Pharmacol Ther 138: 255-271, 2013.

5. Sedlacek HH: Mechanisms of action of flavopiridol. Crit Rev Oncol Hematol 38: 139-170, 2001.

6. Khalil HS, Mitev V, Vlaykova T, Cavicchi L and Zhelev N: Discovery and development of seliciclib. How systems biology approaches can lead to better drug performance. J Biotechnol 202 : 40-49, 2015.

7. Tong WG, Chen R, Plunkett W, Siegel D, Sinha R, Harvey RD, Badros AZ, Popplewell L, Coutre S, Fox JA, et al: Phase I and pharmacologic study of SNS-032, a potent and selective Cdk2, 7, and 9 inhibitor, in patients with advanced chronic lymphocytic leukemia and multiple myeloma. J Clin Oncol 28: 3015-3022, 2010.

8. Strebhardt K and Ullrich A: Targeting polo-like kinase 1 for cancer therapy. Nat Rev Cancer 6: 321-330, 2006.

9. Murugan RN, Park JE, Kim EH, Shin SY, Cheong C, Lee KS and Bang JK: Plk1-Targeted small molecule inhibitors: Molecular basis for their potency and specificity. Mol Cells 32: 209-220, 2011.

10. Kollareddy M, Zheleva D, Dzubak P, Brahmkshatriya PS, Lepsik M and Hajduch M: Aurora kinase inhibitors: Progress towards the clinic. Invest New Drugs 30: 2411-2432, 2012.

11. Boutros R, Lobjois V and Ducommun B: CDC25 phosphatases in cancer cells: Key players? Good targets? Nat Rev Cancer 7: 495-507, 2007. 
12. Lavecchia A, Di Giovanni $C$ and Novellino E: CDC25 phosphatase inhibitors: An update. Mini Rev Med Chem 12: 62-73, 2012.

13. Nigg EA and Nigg EA: Mitotic kinases as regulators of cell division and its checkpoints. Nat Rev Mol Cell Biol 2: 21-32, 2001.

14. Lindqvist A, van Zon W, Karlsson C and Wolthuis RM: Cyclin B1-cdk1 activation continues after centrosome separation to control mitotic progression. PLoS Biol 5: e123, 2007.

15. Lindqvist A, Rodríguez-Bravo V and Medema RH: The decision to enter mitosis: Feedback and redundancy in the mitotic entry network. J Cell Biol 185: 193-202, 2009.

16. Dunphy WG: The decision to enter mitosis. Trends Cell Biol 4: 202-207, 1994.

17. Porter LA and Donoghue DJ: Cyclin B1 and CDK1: Nuclear localization and upstream regulators. Prog Cell Cycle Res 5: 335-347, 2003

18. Harper JW and Elledge SJ: The DNA damage response: Ten years after. Mol Cell 28: 739-745, 2007.

19. Krenning L, Feringa FM, Shaltiel IA, van den Berg J and Medema RH: Transient activation of $\mathrm{p} 53$ in $\mathrm{G} 2$ phase is sufficient to induce senescence. Mol Cell 55: 59-72, 2014.

20. Baus F, Baus F, Gire V, Fisher D, Piette J and Dulić V: Permanent cell cycle exit in G2 phase after DNA damage in normal human fibroblasts. EMBO J 22: 3992-4002, 2003.

21. Müllers E, Cascales HS, Jaiswal H, Saurin AT and Lindqvist A: Nuclear translocation of Cyclin B1 marks the restriction point for terminal cell cycle exit in G2 phase. Cell Cycle 13: 2733-2743, 2014.

22. Lossaint G, Besnard E, Fisher D, Piette J and Dulić V: Chk1 is dispensable for G2 arrest in response to sustained DNA damage when the ATM/p53/p21 pathway is functional. Oncogene 30: 4261-4274, 2011

23. Hayashi MT and Karlseder J: DNA damage associated with mitosis and cytokinesis failure. Oncogene 32: 4593-4601, 2013.

24. Dumontet $\mathrm{C}$ and Jordan MA: Microtubule-binding agents: A dynamic field of cancer therapeutics. Nat Rev Drug Discov 9: 790-803, 2010

25. Perez EA: Microtubule inhibitors: Differentiating tubulin-inhibiting agents based on mechanisms of action, clinical activity, and resistance. Mol Cancer Ther 8: 2086-2095, 2009.

26. Risinger AL, Giles FJ and Mooberry SL: Microtubule dynamics as a target in oncology. Cancer Treat Rev 35: 255-261, 2009.

27. Bhalla KN: Microtubule-Targeted anticancer agents and apoptosis. Oncogene 22: 9075-9086, 2003.

28. Jordan MA and Wilson L: Microtubules as a target for anticancer drugs. Nat Rev Cancer 4: 253-265, 2004.

29. Yi R, Saito K, Isegawa N and Shirasawa H: Alteration of cell cycle progression by Sindbis virus infection. Biochem Biophys Res Commun 462: 426-432, 2015.

30. Yoshida K, Morikawa T, Yokozuka N, Harada S and Nishida A Stereoselective synthesis of chiral hydrocarbazoles via the catalytic diels-alder reaction of siloxyvinylindole and cyclic Z-olefin. Tetrahedron Lett 55: 6907-6910, 2014.

31. Yuan Z, Lourenco SD, Sage EK, Kolluri KK, Lowdell MW and Janes SM: Cryopreservation of human mesenchymal stromal cells expressing TRAIL for human anti-cancer therapy. Cytotherapy 18: 860-869, 2016

32. Jang YJ, Ma S, Terada Y and Erikson RL: Phosphorylation of threonine 210 and the role of serine 137 in the regulation of mammalian polo-like kinase. J Biol Chem 277: 44115-44120, 2002.

33. Kellogg EH, Hejab NM, Howes S, Northcote P, Miller JH, Díaz JF, Downing KH and Nogales E: Insights into the distinct mechanisms of action of taxane and non-taxane microtubule stabilizers from Cryo-EM structures. J Mol Biol 429: 633-646, 2017.
34. Hanwell MD, Curtis DE, Lonie DC, Vandermeersch T, Zurek E and Hutchison GR: Avogadro: An advanced semantic chemical editor, visualization, and analysis platform. J Cheminform 4: 17, 2012.

35. Becke AD: Density-functional thermochemistry. III. The role of exact exchange. J Chem Phys 98: 5648-5652, 1998.

36. Lee C, Yang W and Parr RG: Development of the colle-salvetti correlation-energy formula into a functional of the electron density. Phys Rev B Condens Matter 37: 785-789, 1988.

37. Morris GM, Huey R, Lindstrom W, Sanner MF, Belew RK, Goodsell DS and Olson AJ: AutoDock4 and autodocktools4: Automated docking with selective receptor flexibility. J Comp Chem 30: 2785-2791, 2009.

38. Baker NA, Sept D, Joseph S, Holst MJ and McCammon JA: Electrostatics of nanosystems: Application to microtubules and the ribosome. Proc Natl Acad Sci USA 98: 10037-10041, 2001.

39. Vollmer CM, Ribas A, Butterfield LH, Dissette VB, Andrews KJ Eilber FC, Montejo LD, Chen AY, Hu B, Glaspy JA, et al: P53 selective and nonselective replication of an E1B-deleted adenovirus in hepatocellular carcinoma. Cancer Res 59: 4369-4374, 1999.

40. Yasumura $\mathrm{Y}$ and Kawakita Y: A line of cells derived from African green monkey kidney. Nippon Rinsho 21: 1209-1210, 1963.

41. Castedo M, Perfettini JL, Roumier T, Andreau K, Medema R and Kroemer G: Cell death by mitotic catastrophe: A molecular definition. Oncogene 23: 2825-2837, 2004.

42. Vitale I, Galluzzi L, Castedo M and Kroemer G: Mitotic catastrophe: A mechanism for avoiding genomic instability. Nat Rev Mol Cell Biol 12: 385-392, 2011.

43. Wei Y, Mizzen CA, Cook RG, Gorovsky MA and Allis CD: Phosphorylation of histone $\mathrm{H} 3$ at serine 10 is correlated with chromosome condensation during mitosis and meiosis in tetrahymena. Proc Natl Acad Sci USA 95: 7480-7484, 1998.

44. Crosio C, Fimia GM, Loury R, Kimura M, Okano Y, Zhou H, Sen S, Allis CD and Sassone-Corsi P: Mitotic phosphorylation of histone H3: Spatio-Temporal regulation by mammalian aurora kinases. Mol Cell Biol 22: 874-885, 2002.

45. van Vugt MA and Medema RH: Getting in and out of mitosis with polo-like kinase-1. Oncogene 24: 2844-2859, 2005.

46. Donzelli M and Draetta GF: Regulating mammalian checkpoints through Cdc25 inactivation. EMBO Rep 4: 671-677, 2003.

47. Sakaue-Sawano A,Kobayashi T,OhtawaK and Miyawaki A:DrugInduced cell cycle modulation leading to cell-cycle arrest, nuclear mis-segregation, or endoreplication. BMC Cell Biol 12: 2, 2011.

48. Dalton WB, Yu B and Yang VW: P53 suppresses structural chromosome instability after mitotic arrest in human cells. Oncogene 29: 1929-1940, 2010.

49. Shieh SY, Shieh SY, Ikeda M and Prives C: DNA damage-induced phosphorylation of p53 alleviates inhibition by MDM2. Cell 91: 325-334, 1997

50. Chen W, Yi R, Vahed M, Ohno Y, Tian Z, Guo S, Ma X, Win NN, Li Q, Tsubosaka A, et al: Novel chiral chalcone analogs that induce $\mathrm{M}$ phase arrest and apoptosis in HeLa cells. Med Chem 9: 74-82, 2019.

51. Colin DJ, Hain KO, Allan LA and Clarke PR: Cellular responses to a prolonged delay in mitosis are determined by a DNA damage response controlled by Bcl-2 family proteins. Open Biol 5: 140156, 2014.

52. Dephoure N, Dephoure N, Zhou C, Villén J, Beausoleil SA, Bakalarski CE, Elledge SJ and Gygi SP: A quantitative atlas of mitotic phosphorylation. Proc Natl Acad Sci USA 105: 10762-10767, 2008.

53. Orth JD, Loewer A, Lahav G and Mitchison TJ: Prolonged mitotic arrest triggers partial activation of apoptosis, resulting in DNA damage and p53 induction. Mol Biol Cell 23: 567-576, 2012. 